\title{
Occurrence and pathogenicity of Neofusicoccum parvum and N. mangiferae on ornamental Tibouchina species
}

\author{
R. N. Heath ${ }^{1}$, J. Roux ${ }^{2}$, B. Slippers ${ }^{1}$, A. Drenth ${ }^{3}$, S. R. Pennycook ${ }^{4}$, B. D. Wingfield ${ }^{1}$ and M. J. \\ Wingfield ${ }^{1}$
}

(1) Department of Genetics, Forestry and Agricultural Biotechnology Institute (FABI), University of Pretoria, Pretoria, South Africa.

(2) Department of Microbiology and Plant Pathology, Forestry and Agricultural Biotechnology Institute (FABI), University of Pretoria, Pretoria 0002, South Africa.

(3) Tree Pathology Centre, The University of Queensland, and Department of Primary Industries and Fisheries, Brisbane, Queensland, Australia.

(4) Landcare Research, Auckland Mail Centre, Auckland, New Zealand.

Jolanda Roux

Email: jolanda.roux@fabi.up.ac.za

\begin{abstract}
Species in the Botryosphaeriaceae are important canker pathogens of woody plants, including Eucalyptus spp. The recent discovery of the Eucalyptus pathogen, Chrysoporthe austroafricana, on ornamental Tibouchina trees raised the question as to whether Tibouchina spp. might be alternative hosts for other Eucalyptus pathogens. Therefore, the aim of this study was to consider whether species of the Botryosphaeriaceae occurring on Eucalyptus spp. might also occur on ornamental Tibouchina spp. Isolations were made from Tibouchina trees in South Africa, New Zealand and Australia. Isolates were identified using morphological characteristics and DNA-based techniques. Neofusicoccum parvum and $N$. mangiferae were identified from the samples. Pathogenicity trials on T. urvilleana showed that both species are pathogenic to this host.
\end{abstract}

\section{Introduction}

New host associations of fungal pathogens between species of trees residing in a single genus and even between trees in different families are commonly reported when hosts are for the first time exposed to the pathogens (Slippers and Wingfield 2007). This seemingly easy shift of certain pathogens between tree species, poses a considerable threat to tree-based industries, as well as to the survival of native tree species in their natural ranges. Examples of this process, associated with commercial plantation forestry, include the pathogens Ceratocystis albifundus M.J. Wingf., De Beer \& M.J. Morris, a native to Africa originating from several native tree species, that has adapted to Australian Acacia spp. in Africa (Roux et al. 2007) and Chrysoporthe austroafricana Gryzenh. \& M.J. Wingf., also native to Africa, originating from native Myrtaceae, and that has adapted to infect Australian Eucalyptus spp. (Gryzenhout et al. 2004; Heath et al. 2006). Similar shift of Botryosphaeriaceae between tree species has been reported by Pavlic et al. (2007).

Tibouchina spp. (Myrtales, Melastomataceae), native to high altitude cool areas of south and central America, produce attractive flowers and are commonly planted as ornamentals in southern hemisphere countries such as South Africa, Australia and New Zealand. These trees are also often found in areas where Eucalyptus spp. (Myrtales, Myrtaceae) are grown in plantations. Reports of 
Eucalyptus pathogens occurring on both Eucalyptus and Tibouchina (Gryzenhout et al. 2004) have led to the hypothesis that other Eucalyptus pathogens, such as species in the Botryosphaeriaceae, might also occur on these trees.

The Botryosphaeriaceae include important canker pathogens of numerous plant genera including commercially grown Eucalyptus spp. (Slippers and Wingfield 2007). Symptoms of infection by different species of Botryosphaeriaceae typically include tip die-back, stem cankers, cracking of the bark, kino exudation and tree mortality (Smith et al. 1994). It has been recognized that the Botryosphaeriaceae can infect healthy host tissue and exist in a latent form until the onset of stress (Slippers and Wingfield 2007). Although the Botryosphaeriaceae cause diseases of many economically important crops, they are generally regarded as opportunistic pathogens causing disease only when hosts are weakened or stressed (Slippers and Wingfield 2007).

The aim of this study was to determine whether Botryosphaeriaceae species, known to occur on Eucalyptus spp., also occur on Tibouchina spp. in the same geographical regions. As some Botryosphaeriaceae can be present asymptomatically as endophytes, it is important to identify their host range and pathogenicity from a disease management and quarantine point of view.

\section{Collection of isolates}

Branches from trees showing typical dieback symptoms were collected from scattered Tibouchina urvilleana Cogn. growing as ornamentals in South African gardens in the KwaZulu-Natal Province and from T. lepidota Baill. trees in Auckland, New Zealand and Brisbane, Australia. Samples were collected from healthy, as well as dying branches and were incubated at $5^{\circ} \mathrm{C}$ for 1 week prior to isolation to improve isolation success. Isolations were performed from the branches collected as described by Pavlic et al. (2007).

Botryosphaeriaceae were isolated from both healthy and dead tissue confirming the endophytic nature of these fungi. A total of 23 isolates, seven from Pietermaritzburg (KwaZulu-Natal Province, South Africa) and 16 from KwaMbonambi (KwaZulu-Natal Province, South Africa) were collected from branches of 52 trees sampled in South Africa. Nine of these isolates were from tissue of trees showing no visible symptoms of disease. Six isolates were obtained from six trees in New Zealand and four isolates from four trees in Australia. All isolates are maintained in the culture collection (CMW) of the Forestry and Agricultural Biotechnology Institute (FABI), University of Pretoria, South Africa.

\section{Identification of isolates}

Isolates from Tibouchina spp. were identified based on morphology, restriction fragment length polymorphisms (RFLPs) and DNA sequence comparisons. All isolates were induced to sporulate by transferring them to water agar (20 g Biolab Agar, 11 distilled water), to which sterile pine needles or Tibouchina twigs had been placed on the agar surface. Cultures were incubated at $25^{\circ} \mathrm{C}$ for 2 weeks under near UV light $(280 \mathrm{~nm})$. Fruiting structures produced on the pine needles or Tibouchina twigs were dissected by hand to expose conidia or ascospores. Spores were mounted in lactophenol and examined using Nomarski differentiation interference contrast microscopy. For each isolate, the average length and width (widest point) of 25 conidia was measured using a light microscope (Carl Zeiss, Randburg, Gauteng, South Africa) and these are presented as (min-)(mean $-\mathrm{SD})-($ mean $+\mathrm{SD})(-\max ) \mu \mathrm{m}$. Images were captured electronically with an Axiovision digital camera system (Carl Zeiss). All isolates included in this study produced hyaline, smooth-walled conidia and no teleomorph states were observed in culture. Isolates represented two groups, which could be distinguished based on conidial wall thickness and shape. One group had fusiform, thin- 
walled, aseptate conidia with prominent truncate bases and rounded apices. The size ranges of these conidia were $(14-) 15-17(-18) \times(3-) 4-5(-5) \mu \mathrm{m}$. The second morphologically distinct group, represented by only a single isolate originating from South Africa, had conidia that were fusiform to ovoid, aseptate, thicker-walled, with prominent truncate bases and obtuse apices. The average sizes of these conidia were $(9-) 10-12(-13) \times 4-6 \mu \mathrm{m}$.

Representatives from each morphological group were further identified using RFLPs and DNA sequence comparisons. DNA was extracted from representative isolates using the method described by Murray and Thompson (1980). The internally transcribed spacer (ITS) regions (ITS1 and ITS2), including the 5.8S rDNA gene, were amplified using the primer pair ITS 1 and ITS 4. PCR conditions were as described by Slippers et al. (2004b).

Restriction fragment length polymorphisms were used to confirm the groups of isolates that had been distinguished based on morphology. Amplified PCR products of the ITS regions were digested with the restriction enzyme $C f o \mathrm{I}$ following the method described by Slippers et al. (2004b). Digestion of isolates with the restriction enzyme $C f o$ I supported the separation of the isolates from Australia, New Zealand and South Africa into two groups. All isolates used in the study, except one from South Africa, showed restriction fragment sizes corresponding to those of $N$. parvum (Pennycook \& Samuels) Crous, Slippers \& A.J.L. Phillips, with fragments of 119, 322, 415 and 477 bp (Slippers et al. 2004b). A single isolate from South Africa representing the second morphologically distinct group produced a restriction pattern with fragment sizes of 121 and 269 bp, which corresponds to N. mangiferae (Syd. \& P. Syd.) Crous, Slippers \& A.J.L. Phillips (Jacobs 2002).

A representative set of seven isolates, identified based on morphology and RFLP analyses, were chosen for DNA sequence comparison. Previously published sequences of known Botryosphaeriaceae were included for comparative purposes. Analyses were done using the heuristic search option with TBR (tree bisection-reconnection) branch swapping using the computer software paup (Sinauer Associates, Sunderland, MA, USA). Botryosphaeria dothidea (Moug.:Fr.) Ces. \& De Not, was used as an outgroup taxon to root the phylogenetic tree.

The isolates from Tibouchina spp. resided in two distinct clades based on DNA sequence comparison. The first clade contained $N$. parvum isolates from various hosts and geographic regions. Four of the sequences determined in this study were identical to the ex-type isolate of $N$. parvum (CMW9081 from Populus nigra L. in New Zealand), as well as isolates from Syzygium cordatum Hochst. in South Africa and Malus sylvestris Mill. in New Zealand, or differed from these sequences by a maximum of two, non-informative base pairs. The second clade was typified by $N$. mangiferae isolates from mango (Mangifera indica L.) in Australia (Fig. 1).

\section{Pathogenicity}

To determine the relative pathogenicity of the Neofusicoccum spp. isolated from Tibouchina spp., 1year-old T. urvilleana plants were inoculated in a greenhouse using a fully randomized design. The stem diameters of inoculated trees varied from 10 to $15 \mathrm{~mm}$. Two randomly selected isolates of $N$. parvum and the single $N$. mangiferae isolate, grown on $2 \%$ malt extract agar (MEA) for 7 days, were inoculated into wounds, made with a $5-\mathrm{mm}$ cork borer by removing the bark, on $20 T$. urvilleana trees each with mycelial plugs, $5 \mathrm{~mm}$ in diameter and $\sim 3 \mathrm{~mm}$ thick. The inoculated area was covered with laboratory film to prevent desiccation. Ten additional trees were inoculated with sterile MEA plugs, which served as controls. Trees were maintained at $25^{\circ} \mathrm{C}$ under natural day/night cycles and watered daily. 


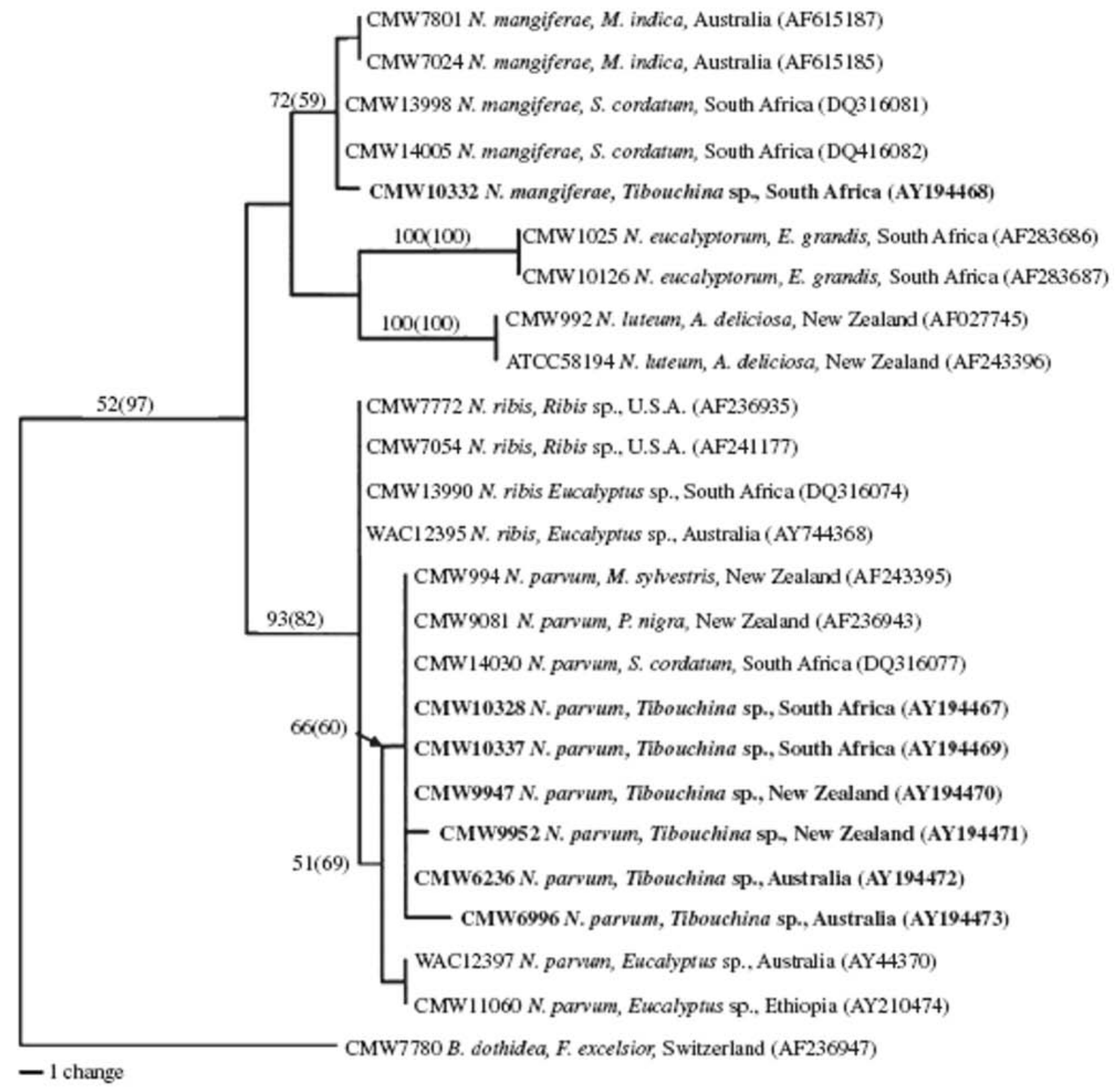

Figure 1. Phylogenetic tree generated from sequence data including ITS (ITS1 and ITS2) and 5.8S regions of the rDNA operon. Bootstrap values (1000 replicates) are indicated at the branches with those lower than 50\% not shown. Bayesian values are indicated in brackets. Botryosphaeria dothidea was used as the outgroup taxon. Sequences generated in this study are indicated in bold.

Lesion lengths were measured 6 weeks after the trees were inoculated. The experiment was repeated once. Data were subjected to analysis of variance (anova) using the General Linear Model procedure of SAS (SAS Statistical Software 1989). To determine whether the inoculated fungi were responsible for the lesion development, re-isolations were made from the lesions and the identity of the isolated fungi was confirmed based on morphology.

Inoculations on T. urvilleana plants resulted in distinct lesions within 6 weeks, whereas the control inoculations produced no lesions. The $N$. mangiferae isolate (CMW10332) produced significantly longer lesions $(\mathrm{p}>0.0001)$ than the two $N$. parvum isolates, with an average lesion length of 28.8 $\mathrm{mm}$ (standard deviation $3.2 \mathrm{~mm}$ ). The two N. parvum isolates (CMW10337 and CMW10328) produced mean lesion lengths of $13.9 \mathrm{~mm}$ (standard deviation $3.4 \mathrm{~mm}$ ) and $14.3 \mathrm{~mm}$ (standard deviation $3 \mathrm{~mm}$ ), respectively. Lesions associated with all isolates differed significantly from the control inoculations $(\mathrm{p}<0.0001)$. The inoculated fungi were consistently re-isolated from the 
lesions.

\section{Discussion}

This is the first study to consider the occurrence of Neofusicoccum on Tibouchina spp., which are widely planted as ornamentals in South Africa, Australia and New Zealand. Neofusicoccum parvum was the most common species on this host in this study and it is apparently not very aggressive. It was interesting that a single isolate of N. mangiferae was also found on Tibouchina in South Africa and that this fungus displayed high levels of pathogenicity.

Neofusicoccum parvum, which was found in all three countries from which samples were collected, is a species that is relatively poorly understood in terms of its geographic distribution and host range. This is because of the confused taxonomic history of the Botryosphaeriaceae, which makes previous records difficult to interpret. Neofusicoccum parvum has often been confused with species such as N. ribis (Slippers, Crous \& M.J. Wingf.) Crous, Slippers \& A.J.L. Phillips, N. luteum (Pennycook \& Samuels) Crous, Slippers \& A.J.L. Phillips and other similar anamorphs (Slippers et al. 2004a) and has previously been reported from all three countries represented in this study. Neofusicoccum parvum has been reported on numerous Eucalyptus spp. and has also been shown as pathogenic to Eucalyptus spp. (Pavlic et al. 2007).

Only one isolate of $N$. mangiferae was isolated from asymptomatic Tibouchina spp. in this study. Neofusicoccum mangiferae is a common pathogen responsible for losses in the mango industry in Australia, where it causes pre- and post-harvest infection of fruit and decline and die-back of trees (Johnson et al. 1992). Extensive surveys of Botryosphaeriaceae in mango plantations in South Africa have, however, not yielded isolates of this fungus (Jacobs 2002). Interestingly, it has recently been isolated from S. cordatum trees (Pavlic et al. 2007) in the same sample area of South Africa that was surveyed in this study. Its limited occurrence and first report on Tibouchina might indicate that this plant species is not a preferred host of the fungus, but it could also be related to the relatively small sample of Neofusicoccum isolates collected in this study. Neofusicoccum mangiferae was highly pathogenic on the Tibouchina trees inoculated. The inoculation of $N$. mangiferae onto Eucalyptus trees in a study by Pavlic et al. (2007) also produced lesions on that host. This fungus could thus be a potentially important pathogen of the Myrtales and it deserves further study.

As with other reports (Smith et al. 1994; Slippers and Wingfield 2007), isolates collected in this study were from symptomatic, as well as asymptomatic tissue. This suggests that both species are able to exist as latent pathogens in Tibouchina trees. This could have serious implications for quarantine as the endophytic nature of the fungi on these hosts could facilitate their spread to new environments, particularly because they would be difficult to detect using typical quarantine systems. Information regarding the diversity of these endophytes/latent pathogens, their role in the environment in which they occur and the factors that influence their pathogenicity, are needed to establish more effective quarantine strategies.

\section{Acknowledgments}

Members of the Tree Protection Co-operative Programme (TPCP), the National Research Foundation (NRF) and the THRIP initiative of the Department of Trade and Industry, South Africa provided financial support for which we are most grateful. We also acknowledge the assistance of the late Dr B. E. Eisenberg with statistical analysis of the inoculation trial data. 


\section{Literature Cited}

Gryzenhout, M.; Myburg, H.; Van der Merwe, N. A.; Wingfield, B. D.; Wingfield, M. J., 2004: Chrysoporthe, a new genus to accommodate Cryphonectria cubensis. Stud. Mycol. 50, 119-142.

Heath, R. N.; Gryzenhout, M.; Roux, J.; Wingfield, M. J., 2006: Discovery of the Cryphonectria canker pathogen on native Syzygium species in South Africa. Plant Dis. 90, 433-438.

Jacobs, R., 2002: Characterisation of Botryosphaeria species from Mango in South Africa. M.Sc Thesis. Department of Microbiology and Plant Pathology, University of Pretoria, Pretoria, South Africa. pp. 120-147.

Johnson, G. I.; Mead, A. J.; Cooke, A. W.; Dean, J. R., 1992: Mango stem end rot pathogens: fruit infection by endophytic colonization of the inflorescence and pedicle. Ann. Appl. Biol. 120, 225234.

Murray, M. G.; Thompson, W. F., 1980: Rapid isolation of high molecular weight plant DNA. Nucleic Acids Res. 8, 4321-4325.

Pavlic, D.; Slippers, B.; Coutinho, T. A.; Wingfield, M. J., 2007: Botryosphaeriaceae occurring on native Syzygium cordatum in South Africa and their potential threat to Eucalyptus. Plant Pathol. 56, 624-636.

Roux, J.; Heath, R. N.; Labuschagne, L.; Kamgan Nkuekam, G.; Wingfield, M. J., 2007: Occurrence of the wattle wilt pathogen, Ceratocystis albifundus on native South African trees. Forest Pathol. 37, 292-302.

SAS Statistical Software, 1989: SAS STAT User\#s Guide, Version 6, 4th edn, Vol. 1 \& 2. SAS Institute Inc., Cary, NC.

Slippers, B.; Wingfield, M. J., 2007: Botryosphaeriaceae species as endophytes and latent pathogens of woody plants: diversity, ecology and impact. Fungal Biol. Rev. 21, 90-96.

Slippers, B.; Crous, P. W.; Denman, S.; Coutinho, T. A.; Wingfield, B. D.; Wingfield, M. J., 2004a: Combined multiple gene genealogies and phenotypic characters differentiate several species previously identified as Botryosphaeria dothidea. Mycologia 96, 83-101.

Slippers, B.; Fourie, G.; Crous, P. W.; Coutinho, T. A.; Wingfield, B. D.; Carnegie, A.; Wingfield, M. J., 2004b: Speciation and distribution of Botryosphaeria spp. on native and introduced Eucalyptus trees. Stud. Mycol. 50, 343-358.

Smith, H.; Kemp, G. H. J.; Wingfield, M. J., 1994: Canker and die-back of Eucalyptus in South Africa caused by Botryosphaeria dothidea. Plant Pathol. 43, 1031-1034. 